\title{
Formation of upland rice drought-tolerant mutants by mutation induction and in vitro selection
}

\author{
ROSSA YUNITA`, ISWARI S. DEWI, ENDANG GATI LESTARI, RAGAPADMI PURNAMANENGSIH, \\ SUCI RAHAYU, MASTUR \\ Indonesian Center for Agricultural Biotechnology and Genetic Resource Research and Development. J1. Tentara Pelajar No. 3A, Cimanggu, Bogor \\ 16111, West Java, Indonesia. Tel.: +62-251-8337975, Fax: +62-251-8338820, `email: rossa_yunita@yahoo.com
}

Manuscript received: 22 January 2020. Revision accepted: 18 March 2020.

\begin{abstract}
Yunita R, Dewi IS, Lestari EG, Purnamanengsih R, Rahayu S, Mastur. 2020. Formation of upland rice drought-tolerant mutants by mutation induction and in vitro selection. Biodiversitas 21: 1476-1482. Increased production can be done by increasing the planting area, but the available land is sub-optimal land with drought stress. Drought-tolerant rice varieties are needed to utilize this land. To create drought-tolerant rice can use induction mutation and in vitro selection methods. This study aims to obtain tolerant upland rice mutants through mutation and in vitro selection. The parents used were Batutegi and Situpatenggang varieties. This research consisted of several main activities, namely callus induction, determination of LD 50\% value ofPEG determination of LC 50\% value of gamma-ray irradiation, mutation induction and in vitro selection, bud regeneration and acclimatization. The results of this study are mutant callus formed by gamma-ray irradiation at a dose of $24.68 \mathrm{~Gy}$ for Situpatenggang and 22.15 Gy for Batutegi (LD50) and selected on PEG media at a dose of $24.11 \%$ for Situpatenggang and $25.18 \%$ for Batutegi (LC50). The mutant callus regenerated on MS + BA 3 $\mathrm{mg} / \mathrm{L}+$ Zeatin $0.1 \mathrm{mg} / \mathrm{L}$ produced 83 Situpatenggang shoots and 73 Batutegi shoots and successfully acclimatized were 52 Situpatenggang lines and 49 Batuteg linesBatutegi
\end{abstract}

Keywords: Batutegi, gamma irradiation, LD $50 \%$ value of $\mathrm{NaCl}$, Oryza sativa, Situpatenggang

\section{INTRODUCTION}

Rice (Oryza sativa) is very sensitive to drought stress. Lack of water will interfere with many cellular functions in plants and negatively affect plant growth and reproduction (Bray 2001). The response of rice plants to drought stress depends on the severity of the drought, growth phase (Kadir 2011), and genotypes (Castillo et al. 2006). Drought in the vegetative phase can inhibit leaf growth and roots, reduce the number of tillers and changes in root patterns (Mostajeran and Eichi 2009; Audebert et al. 2013), in the reproductive phase. Drought stress at panicle initiation will reduce panicle dry weight and number of grains per panicle, which has an impact on decreasing grain yield. This is caused by a decrease in photosynthesis, thereby reducing the production of assimilates for panicle growth and filling of grain (Akram et al. 2013). Drought stress not only suppresses growth and yield but also causes plant death (Djazuli 2010).

One way to overcome this problem is to use varieties that are tolerant to drought. Drought-tolerant plants are capable of adapting to drought conditions, which are shown by grain yields that do not decrease significantly (Haque et al. 1992). Drought-tolerant rice varieties are needed if dry season events are unpredictable, as is often the case lately (Pantuwan et al. 2002). Many techniques that can be used to assemble varieties are tolerant to drought, both conventional and non-conventional. One technique that can be used to assemble drought-tolerant varieties is the method of mutation induction combined with in vitro selection.

Mutation induction method using gamma-ray irradiation is an effective method for increasing genetic diversity. Mutation induction techniques in combination with in vitro selection, can increase genetic diversity and increase the chances of obtaining new varieties that adapt to certain environments (Husni et al. 2006). Mutation induction techniques combined with in vitro selection have been shown to produce varieties that are tolerant of water shortages (drought), salinity, aluminum stress or pest and disease stresses. This technique is considered a breakthrough in promising plant breeding. This technique can accelerate the acquisition of new varieties with certain superior properties.

In vitro selection to obtain a genotype that is tolerant to drought can use selection agents in the form of osmotic compounds that can simulate dry conditions in the field. The osmotic compound that expresses the most dryness in the field is PEG. (Dami and Hughes 1997). This method has been tested on sugarcane (Rai et al. 2011; Mahmood et al. 2012; Hartati et al. 2018), Shorgum (Tsago et al. 2014), Rice (Wani et al. 2010; Joshi et al. 2011). The purpose of this study was to obtain plantlets of drought-tolerant upland rice mutants through mutations and in vitro selection. 


\section{MATERIALS AND METHODS}

The plant material used was Situpatenggang and Batutegi rice varieties. This research consists of several activities, namely: callus induction, mutation induction by gamma-ray irradiation and in vitro callus selection, mutation induction and in vitro callus selection, callus regeneration, acclimatization of putative mutant plantlets.

\section{Callus induction}

This study uses a completely randomized design. The treatment was $2,4 \mathrm{D}$ concentrations $(0,1,3$ and $5 \mathrm{mg} / \mathrm{L})$ with 10 replications. The explants used were zygotic embryos isolated from mature seeds. Sterilized seeds using sterile ingredients, including alcohol and chlorox. The embryos were then planted on callus induction media, namely, MS media contain 2,4-D (0,1, 3 and 5) $\mathrm{mg} / \mathrm{L}$ and Casein Hirolisate $3 \mathrm{~g} / \mathrm{L}$. In one bottle has ten explants and sterilized incubated on the culture shelf in the dark. The room temperature is $24-25^{\circ} \mathrm{C}$. The variables observed were the percentage of embryonic callus formation, as well as a visual callus. Callus induction is performed repeatedly in order to obtain embryonic callus in large quantities.

\section{Mutation induction by gamma-ray irradiation and callus in vitro selection \\ Determination of lethal dose $50\left(L D_{50}\right)$ gamma-ray irradiation on callus}

Callus were given irradiation treatment at concentrations $10,20,30,40,50,60,70,80,90$ and $100 \mathrm{~Gy}$, , each treatment consisted of 50 . The observed variable is the percentage of brown callus after four weeks. Data were analyzed to determine the lethal concentration. Determination of lethal concentration 50 (LC50), using program CurveExpet 1.3.

\section{Determination of PEG Lethal Concentration 50 (LC50) on callus of rice}

Callus induced from mature embryos were cultured in medium containing PEG that consists of multiple level concentrations of $0,10,20,30,40$ and $50 \mathrm{mM}$, treatment consisted of 10 replicates, each replicates consisting 5 explants. Variables measured were the number of browning callus. Data were analyzed to determine the lethal concentration. Determination of lethal concentration 50 (LC50), using the regression equation to find the equation of the best. The length of incubation callus in selection medium containing PEG is 4 weeks.

\section{Formation of PEG-tolerant callus mutants using mutation} induction by gamma-ray irradiation and in vitro callus selection

Callus formed was given irradiation treatment. The gamma-ray irradiation dose given is LD50 Callus acclimatization which has been given mutation treatment is then transferred to the same medium for callus induction for four days. Callus that has been treated with mutations, transferred to callus proliferation media, added PEG as much as LC50 values for each variety. Callus from the selection medium after two weeks was cultured on the same medium with the same PEG content for two weeks.
Selection is carried out for two periods and each period for two weeks. The variables observed are the number of browning callus.

\section{Callus regeneration}

This research uses a factorial completely randomized design. The first factor is BA concentration, the second factor is zeatin concentration. This research uses a factorial completely randomized design. The first factor is BA concentration, the second factor is zeatin concentration. The surviving callus on the selection medium was transferred to shoot regeneration media namely: MS contain BA (3, 5, $7 \mathrm{mg} / \mathrm{L})$ and Zeatin $(0,0.1,0.3 \mathrm{mg} / \mathrm{L})$. The variables observed were percent regenerated callus forming whole plantlets in each rice variety used.

\section{Plantlets acclimatization}

This research uses a completely random design. The treatment is in vitro shoot varieties (Situpatengang and Batutegi varieties). The resulting plantlets were acclimatized by means of the resulting plantlets being removed from the agar media and cultured on ordinary water media at room temperature. After the plantlets are able to form new roots, then plantlets are planted in mud media. The variables observed were percent of plantlets that lived in each rice variety.

\section{RESULTS AND DISCUSSION}

\section{Callus induction}

The $2,4 \mathrm{~d}$ concentration treatment had a significant influence on the percentage of callus formed and embryonic callus in situpatengan and batutegi varieties. In the second week after planting zygotic embryo explants began to respond with swelling of the explants and began to form a callus. Explants cultured on media without 2,4-D were unable to form callus, different conditions for explants cultured on media containing 2,4-D could form callus (Table 1). Some research results indicate that 2,4-D is an effective auxin for initiating callus formation from zygotic embryos in various rice varieties (Bona et al. 2005; Tariq et al. 2008).

In Table 1 , it can be seen that 2,4-D $3 \mathrm{mg} / \mathrm{L}$ of Situpatenggang and Batutegi varieties can induce $94 \%$ of callus, $70 \%$ of them are embryogenic in Situpatenggang varieties and $72 \%$ for Batutegi varieties. Increasing 2,4-D concentration to $5 \mathrm{mg} / \mathrm{L}$ can reduce the ability of explants to form callus and the percentage of embryogenic callus also decreases. Thus the concentration of 2,4-D $3 \mathrm{mg} / \mathrm{L}$ is the optimum concentration for forming callus in explants of upland rice embryos of Batutegi varieties and Situpatenggang. The same thing also happened in Fatmawati varieties where the best media for induction of embryogenic callus was enriched media with $2.4 \mathrm{D} 3 \mathrm{mg} / \mathrm{L}$ (Lestari and Yunita 2008).

The rice callus of the Situpatenggang variety and the Batutegi produced on the medium containing 2,4-D $3 \mathrm{mg} / \mathrm{L}$ were embryogenic in which the callus was yellowish-white, nodular and crumb (easily separated). 
Table 1. Effect of 2,4-D concentration on callus formation in some upland rice varieties aged 8 weeks after planting

\begin{tabular}{ccccc}
\hline \multirow{2}{*}{$\begin{array}{c}\text { Concentration } \\
\text { of 2,4-D } \\
(\mathbf{M g} / \mathbf{L})\end{array}$} & $\begin{array}{c}\text { Situpatenggang } \\
\text { formation } \\
(\boldsymbol{\%})\end{array}$ & $\begin{array}{c}\text { Embriogenic } \\
\text { callus (\%) }\end{array}$ & $\begin{array}{c}\text { Callus } \\
\text { formation } \\
(\boldsymbol{\%})\end{array}$ & $\begin{array}{c}\text { Embriogenic } \\
\text { callus (\%) }\end{array}$ \\
\hline 0 & 0 & 0 & 0 & 0 \\
1 & 46 & 23 & 58 & 39 \\
3 & 94 & 70 & 94 & 72 \\
5 & 83 & 35 & 95 & 53 \\
\hline
\end{tabular}

\section{Mutation induction with gamma-ray irradiation and in vitro selection of callus}

Determination of lethal dose $50\left(L D_{50}\right)$ gamma-ray

irradiation on callus

Irradiation treatments showed different percentages of browning callus. The higher the dose of gamma irradiation given, the higher the percentage of browning callus (Figure 1) which shows the characteristics of death in callus (Agisimanto et al. 2016). The callus that has been irradiated will experience browning because of the degradation of the enzyme indolacetol dehydrogenase which plays a role in the biosynthesis of IAA needed to regenerate somatic cell populations.

Figures 1 and 2 show the percentage of dead callus in line with the increase in irradiation dose. For Situpatenggang variety rice and Batutegi, giving irradiation dose of 30 Gy causes death in callus above $50 \%$. Increased radiation dose of less than 30 Gy callus death more than $70 \%$.

The results of the best curve-fit analysis program to determine the lethal dose of 50 (LD50), obtained the best model equation based on the number of dead callus is $\mathrm{Y}=$ $3.49+2,2 \mathrm{X}-0,01 \mathrm{X} 2$ for Situpatenggang varieties and $\mathrm{Y}=$ $8,35+2.16 \mathrm{X}-0.00 \mathrm{X} 2$ for Batutegi. The lethal dose of $50 \%$ (LD50) based on the percentage of dead callus until four weeks after irradiation obtained lethal value of LD50 dose for Situpatenggang variety is 24.68 Gy while for Batutegi variety is 22.152 Gy. This is in line with the results of other studies that obtained different LD50 values for several rice varieties in the callus phase, for Binnatoa varieties is $5.0 \mathrm{~Gy}$ and for varieties of Pokali, BR-16 and BR-26 is 4.0 Gy (Hossain and Alam 2001). While the LD50 value of rice varieties Bastami is 50 Gy (Saleem et al. 2005).

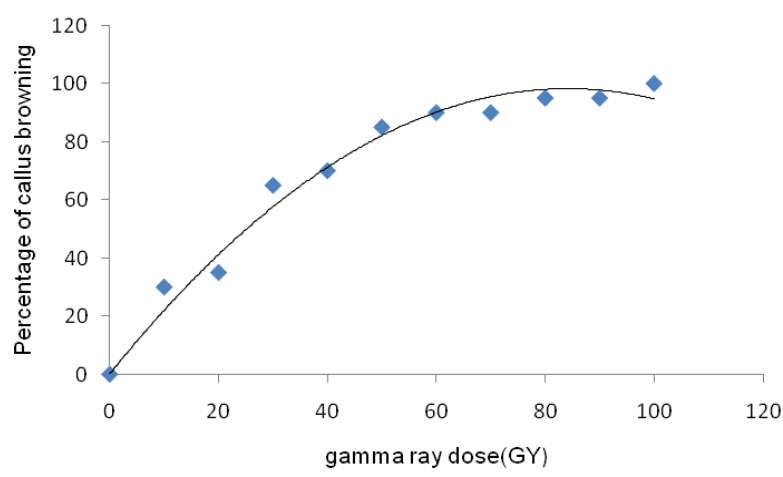

A

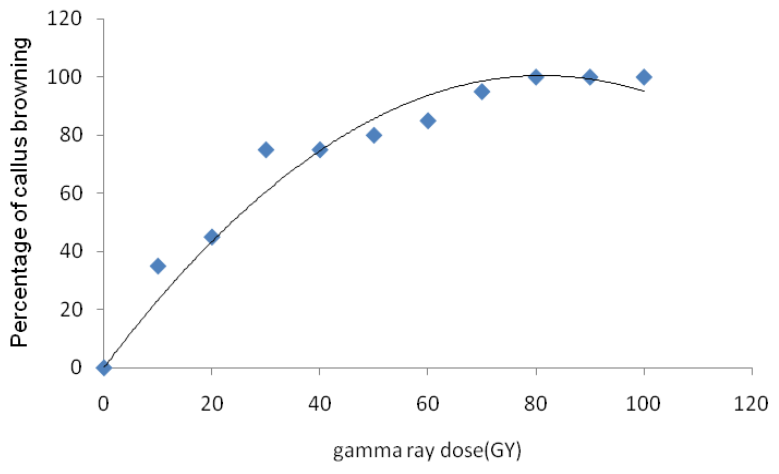

Figure 1. Percentage of browning callus, varieties of Situpatenggang (A) and Batutegi (B)

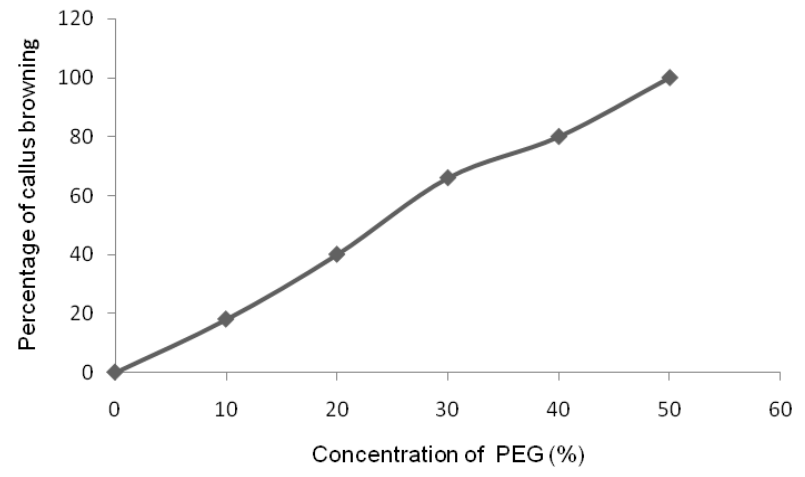

A

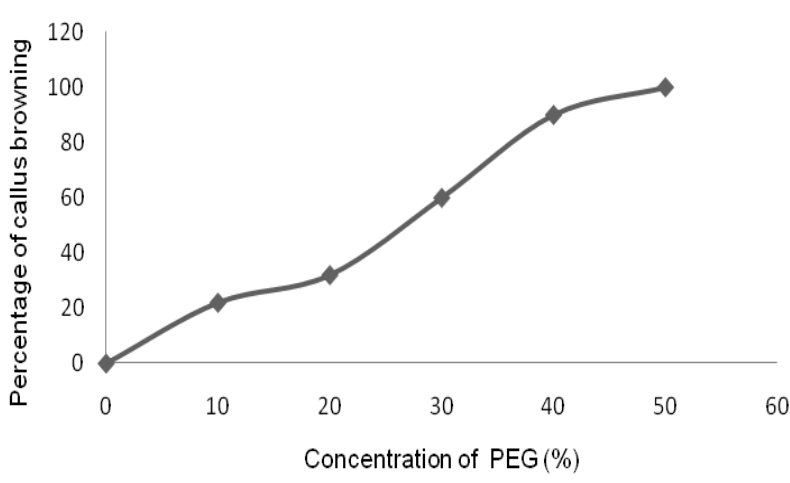

B

Figure 3. Percentage of callus browning on media containing PEG (A) Situpatenggang variety and (B) Batutegi 
Determination of PEG lethal concentration 50 (LC50) on callus of rice

In Table 2, it can be observed that an increase in the concentration of PEG given will increase the number of browning callus. In Table 2 and Figures 3 and 4, it appears that an increase in PEG concentration results in an increase in the percentage of brown callus. For Situpatenggang and Batutegi rice callus, the 30 PEG treatment resulted in more than $40 \%$ brown callus. With increasing PEG concentration, it shows that somatic cells and plant tissue are not able to adjust to the increase in PEG concentration due to osmotic stress. Selected callus line grew better than non-selected callus when grown on different concentrations (Rao and Zabeen 2013).

The results of the best-fit curve analysis program to determine the lethal concentration of 50 (LC50), the best model equation obtained based on the number of brown callus can be seen in Table 3 and Figure 3 and 4. based on the LC50 PEG value, it can be seen the sensitivity level of varieties to PEG.

Table 3. shows that each variety has a different sensitivity to PEG. Batutegi variety has the highest LC50 value of $25.18 \%$ followed by $24.11 \%$ Situpatenggang. This shows that the Batutegi variety is slightly more tolerant of drought than Situpateng.

Formation of PEG-tolerant callus mutants using mutation induction by gamma-ray irradiation and in vitro callus selection

The embryogenic callus was cultured on MS media and then irradiated according to LD50. After being irradiated, the callus was transferred to the callus induction medium for recovery, restoring the callus and detecting contamination. Furthermore, the callus was selected on media containing PEG at LC50 concentration. After four days on callus selection media began to brown, the structure became soft. This shows the callus cells began to experience damage due to radiation stress and selection.

The callus responses of each variety to PEG varied. In the Situpatenggang variety, the percentage of brown callus was $61.66 \%$ and Batutegi was $61 \%$ (Table 4). Each variety has a different response to gamma-ray radiation (Yunita et al. 2014)

\section{Selection of callus regeneration}

In the 4th week after being planted on regeneration media, the callus starts to change. callus forms green spots even though the percentage is still small. Observation on the eighth week looks bud already appeared.

For the parameters of the number of shoots on callus varieties Situpatenggang, the treatment of BA $3 \mathrm{mg} / \mathrm{L}$ and Zeatin $0.1 \mathrm{mg} / \mathrm{L}$ gave the best response where the average number of shoots was 2.3. In the treatment of BA $3 \mathrm{mg} / \mathrm{L}$ and Zeatin $0.3 \mathrm{mg} / \mathrm{L}$, there was a decrease in the number of adventitious shoots to 0.15 (Table 5). This shows that increasing the concentration of zeatin can reduce the number of shoots formed. The same thing happened in cotton plant callus, increasing Zeatin content in growing media will reduce the ability of callus to form adventitious shoots (Lashari et al. 2008).

In the callus Batutegi variety, media containing BA 3 $\mathrm{mg} / \mathrm{L}$ combined with Zeatin $0.1 \mathrm{mg} / \mathrm{L}$ were able to induce $95 \%$ shoot formation with a total number of shoots of 2.6. This treatment is the best treatment for shoot induction in rice varieties of Batutegi variety. Increasing BA to $5 \mathrm{mg} / \mathrm{L}$ reduced the ability of callus to form shoots by $15 \%$ (Table 5). In this variety callus cultured on media without BA and Zeatin were unable to form adventitious shoots, because the callus requires cytokines to regenerate to form shoots (Ikeuchi et al. 2013).

From the above activities, the best medium for callus regeneration to form shoots in Situpatenggang and Batutegi varieties was MS Media which added BA $0.3 \mathrm{mg} / \mathrm{L}$ and Zeatin $0.1 \mathrm{mg} / \mathrm{L}$. This formulation is used to regenerate calluses that have been mutated with gamma-ray irradiation at LD50 concentrations and selected on PEG media at LC50 concentrations.

In Table 6 it can be seen that from 115 callus Situpatenggangg that were cultured on regeneration media, 83 callus which was able to form buds mean number of shoots was 1.2. In the Batutegi variety, of the 117 cultured calli, 73 calluses were able to form buds with an average number of 1.3 shoots (Figure 5).

Table 2. Percentage of callus browning on media containing PEG

\begin{tabular}{ccc}
\hline $\begin{array}{c}\text { Concentration of PEG } \\
(\mathbf{m M})\end{array}$ & \multicolumn{2}{c}{ Variety } \\
\cline { 2 - 3 } & Situpatenggang $(\%)$ & Batutegi (\%) \\
\hline 0 & 0 & 0 \\
10 & 18 & 22 \\
20 & 40 & 32 \\
30 & 66 & 60 \\
40 & 80 & 90 \\
50 & 100 & 100 \\
\hline
\end{tabular}

Table 3. The lethal concentration value of 50 (LC50) PEG of several upland rice varieties

\begin{tabular}{lc}
\hline Variety & LC50 value $(\boldsymbol{\%})$ \\
\hline Situpatenggang & 24.11 \\
Batutegi & 25.18 \\
\hline
\end{tabular}

Table 4. In vitro selection of mutant callus on media containing PEG with LC50 concentration

\begin{tabular}{lccc}
\hline Variety & $\begin{array}{c}\text { Number of } \\
\text { explants }\end{array}$ & $\begin{array}{c}\text { Browning } \\
\text { callus (\%) }\end{array}$ & $\begin{array}{c}\text { Callus } \\
\text { performance }\end{array}$ \\
\hline Situpatenggang & 300 & 61.66 & Callus browning \\
Batutegi & 300 & 61 & Callus browning \\
\hline
\end{tabular}


Table 5. Regeneration of callus forming shoots in Situpatenggang and Batutegi varieties

\begin{tabular}{|c|c|c|c|c|c|c|c|c|}
\hline \multirow{3}{*}{$\begin{array}{l}\text { Concentration } \\
\text { of zeatin }(\mathrm{Mg} / \mathrm{L})\end{array}$} & \multicolumn{8}{|c|}{ Concentration of $\mathrm{Ba}(\mathrm{Mg} / \mathrm{L})$} \\
\hline & \multicolumn{2}{|c|}{$\mathbf{0}$} & \multicolumn{2}{|r|}{3} & \multicolumn{2}{|l|}{5} & \multicolumn{2}{|c|}{7} \\
\hline & $\begin{array}{c}\text { Callus forms } \\
\text { shoots }(\%)\end{array}$ & $\begin{array}{c}\text { Number of } \\
\text { shoots }\end{array}$ & $\begin{array}{c}\text { Callus forms } \\
\text { shoots }(\%)\end{array}$ & $\begin{array}{c}\text { Number of } \\
\text { shoots }\end{array}$ & $\begin{array}{c}\text { Callus forms } \\
\text { shoots }(\%)\end{array}$ & $\begin{array}{c}\text { Number of } \\
\text { shoots }\end{array}$ & $\begin{array}{c}\text { Callus forms } \\
\text { shoots }(\%)\end{array}$ & $\begin{array}{c}\begin{array}{c}\text { Number of } \\
\text { shoots }\end{array} \\
\end{array}$ \\
\hline \multicolumn{9}{|c|}{ Situpatenggang } \\
\hline 0 & 0 & 0 & 5 & 0.05 & 20 & 0.6 & 5 & 0.1 \\
\hline 0.1 & 15 & 0.15 & 85 & 2.3 & 20 & 0.2 & 25 & 0.15 \\
\hline 0.3 & 25 & 0.35 & 25 & 0.15 & 20 & 0.15 & 0 & 0 \\
\hline \multicolumn{9}{|l|}{ Batutegi } \\
\hline 0 & 0 & 0 & 10 & 0.1 & 25 & 0.5 & 10 & 0.2 \\
\hline 0.1 & 10 & 0.15 & 95 & 2.6 & 15 & 0.15 & 25 & 0.35 \\
\hline 0.3 & 35 & 0.65 & 20 & 0.3 & 15 & 0.25 & 10 & 0.15 \\
\hline
\end{tabular}

苞

0

20
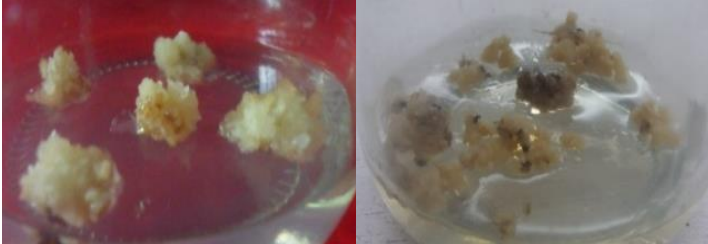

40

60

100

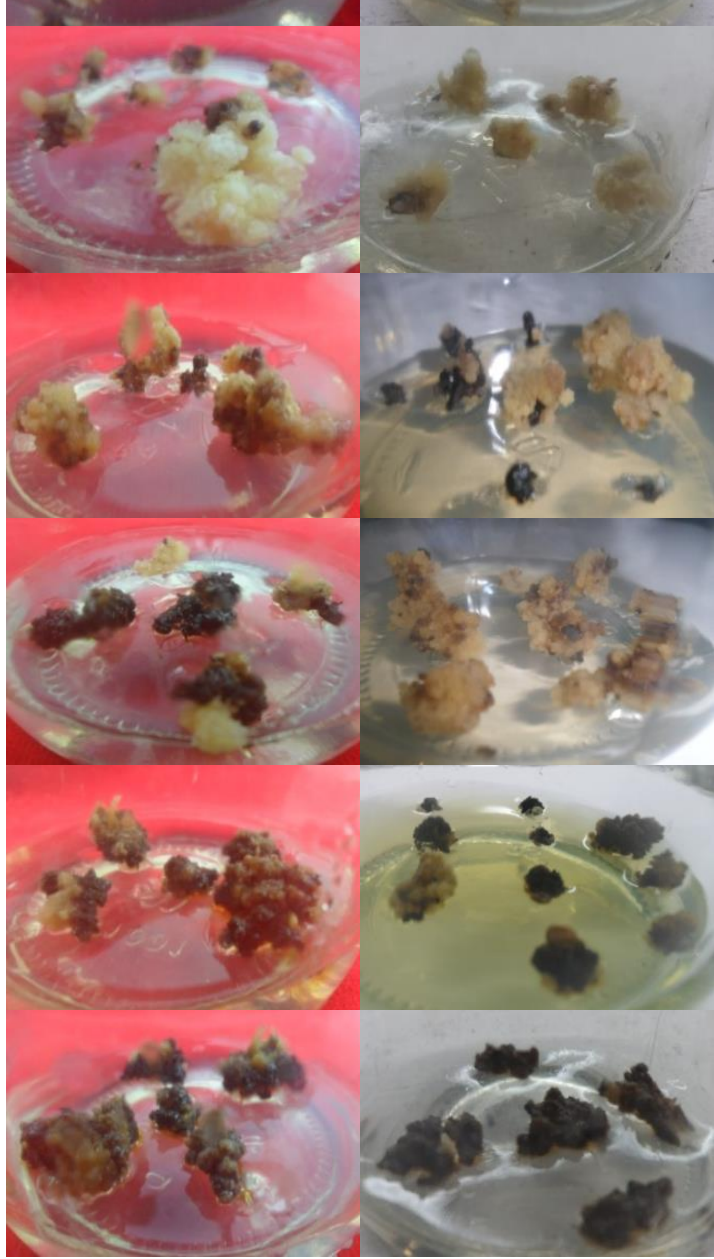

Figure 3. Rice callus performance Situpatenggang and Batutegi after irradiated gamma rays

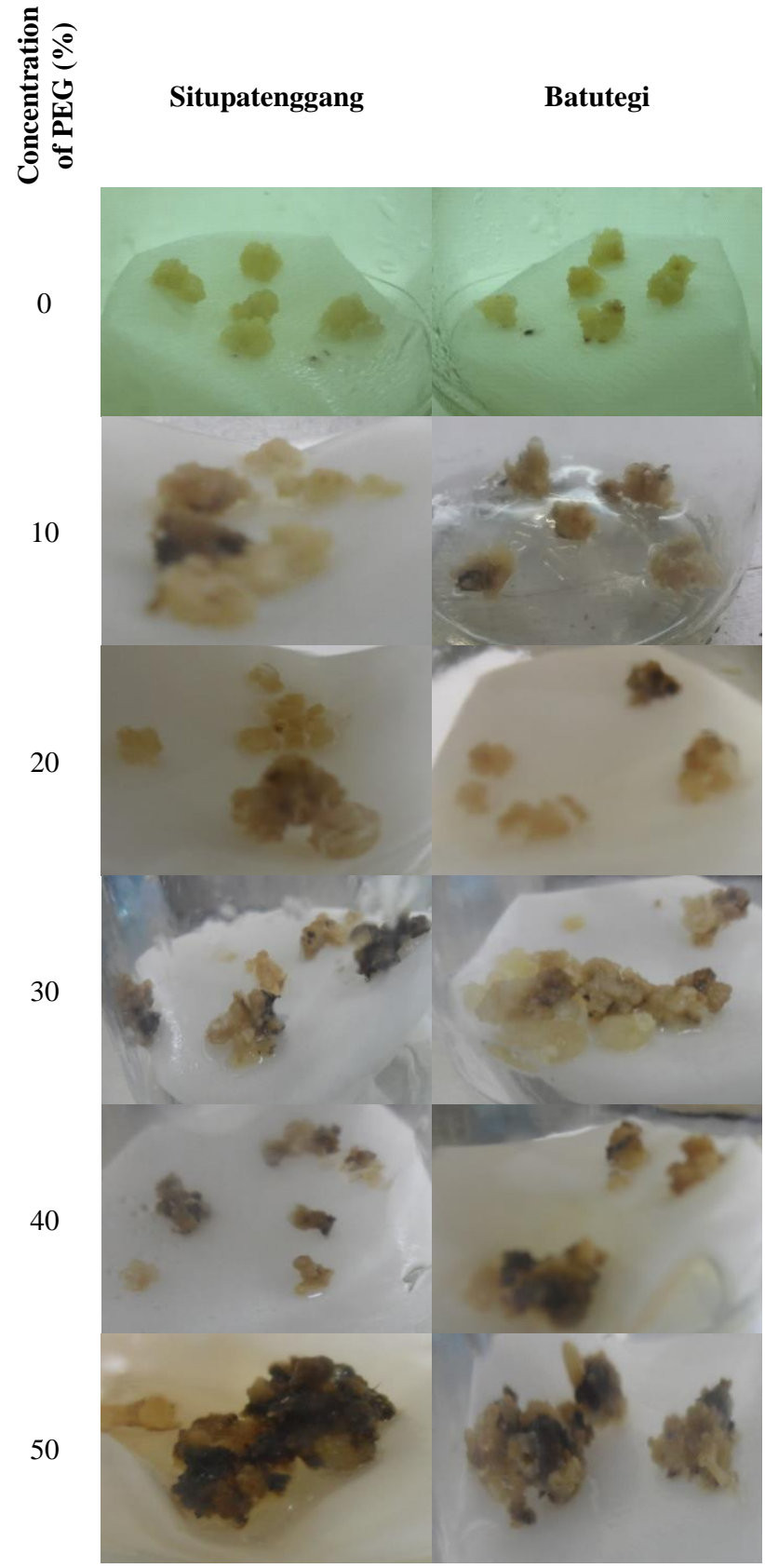

Figure 4. Performance of callus varieties of Situpatenggang and Batutegi after PEG treatment 


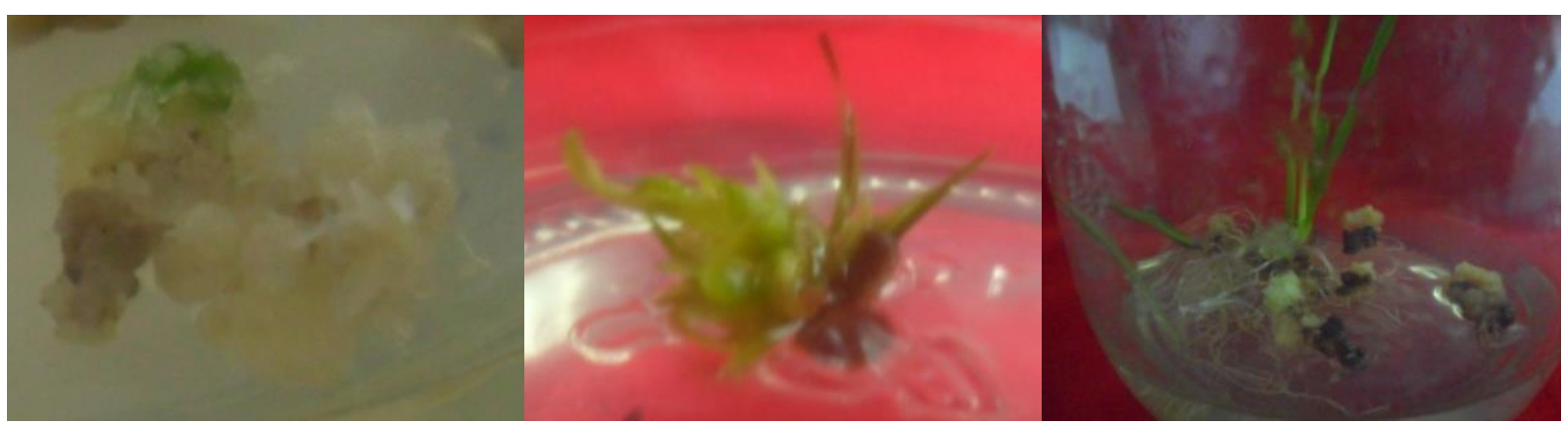

Figure 5. Callus Situpatenggang regenerating to form shoots

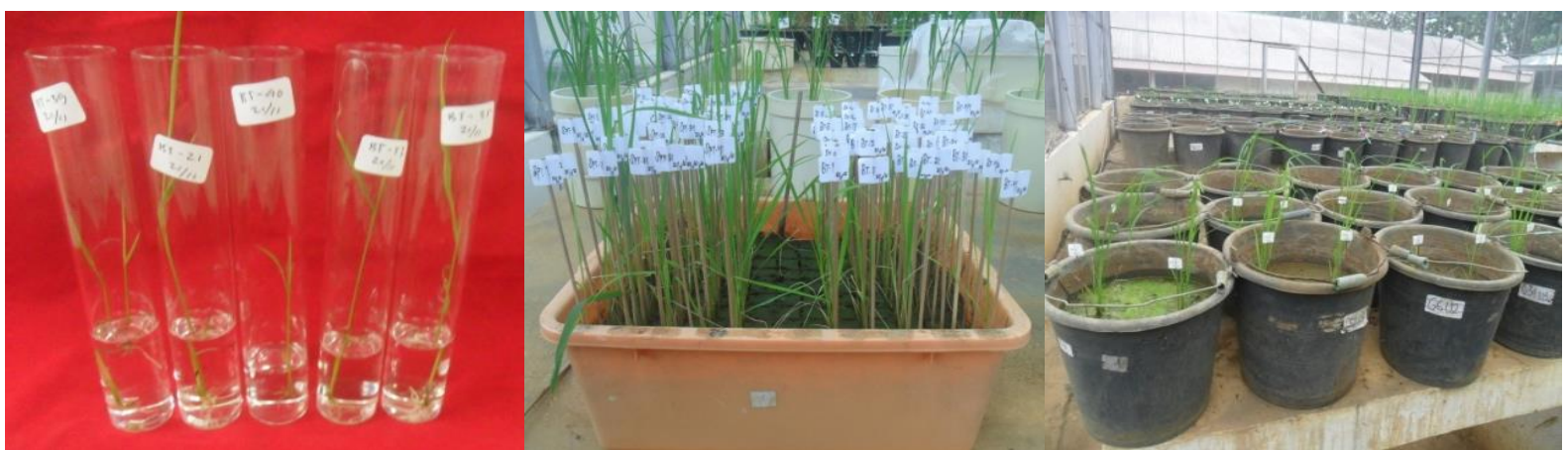

Figure 6. acclimatization process of putative numbers of somaclon mutants

Table 6. Regeneration of selected callus

\begin{tabular}{lccc}
\hline Varieties & $\begin{array}{c}\text { Number of } \\
\text { mutant calluses } \\
\text { selected }\end{array}$ & $\begin{array}{c}\text { Callus } \\
\text { forms buds }\end{array}$ & $\begin{array}{c}\text { The average } \\
\text { number of } \\
\text { shoots per callus }\end{array}$ \\
\hline Situpatenggang & 115 & 83 & 1,2 \\
Batutegi & 117 & 73 & 1,3 \\
\hline
\end{tabular}

\section{Acclimatization}

Acclimatization is an important stage, especially in plants resulting from in vitro culture, because in general, the roots of plantlets derived from in vitro culture have different structures so that the ability at the time of adaptation during acclimatization is not the same (Chandra et al. 2010). The percentage of successful acclimatization is usually very low, so the treatment and environmental conditions determine the success of acclimatization (Sharma 2017). To adjust to the environmental conditions acclimatization carried out in a way, plantlets were cultured on ion free for a week later after the plantlet was able to remove the new roots in which the plantlet was transferred to the mud media.

In Table 7, it can be observed that 70 plantlets derived from Situpatenggang variety rice have a number of living plantlets which is equal to 52. For Batutegi varieties, the number of plantlets acclimatized is 70 with the number of living plantlets being 49 plantlets (Table 7, Figure 6).
Table 7. Acclimatization of mutant plantlets

\begin{tabular}{lcc}
\hline Variety & $\begin{array}{c}\text { Number of } \\
\text { plantlets }\end{array}$ & $\begin{array}{c}\text { Plantlets remain } \\
\text { green after } \\
\text { acclimatization }\end{array}$ \\
\hline Situpatenggang & 70 & 52 \\
Batutegi & 70 & 49 \\
\hline
\end{tabular}

In conclusion, formation of upland rice mutants (drought-tolerant Situpatengang and Batutegi varieties) was carried out by callus mutation with gamma rays at a dose of 24.68 Gy for Situpatenggang and 22.15 Gy for Batutegi (LD50) and selected on PEG media at a dose of $24.11 \%$ for Situpatenggang and $25.18 \%$ for Batutegi (LC50). The mutant callus was regenerated on $\mathrm{MS}+\mathrm{BA} 3 \mathrm{mg} / \mathrm{L}+$ Zeatin $0.1 \mathrm{mg} / \mathrm{L}$ resulted in 83 Situpatenggang shoots and 73 Batutegi shoots. The shoots were acclimatized and produced 52 Situpatenggang lines and 49 Batutegi lines. The mutants produced need to be tested on land with drought stress. Selection is done in the vegetative and generative phases to get mutants that have higher yields than their parents. 


\section{ACKNOWLEDGEMENTS}

The authors would like to acknowledge the Indonesian Agency for Agricultural Research and Development for financial support of this project.

\section{REFERENCES}

Agisimanto D, Mohd Noor N M, Ibrahim R, Mohamad A. 2016. Gamma irradiation effect on embryogenic callus growth of Citrus reticulate cv. Limau Madu. Sains Malaysiana 45 (3): 329-337.

Akram HM, Ali A, Sattar A, Rehman HSU, Bibi A. 2013. Impact of water deficit stress on various physiological and agronomic traits of three basmati rice Oryza sativa L. ) cultivar. J Anim Sci 23 (5): 1415-1423.

Audebert A, Asch F, Dingkuhn M. 2013. Morphophysiological research on drought tolerance in rice at WARDA. Field screening in drought tolerance in crop plants with emphasis on rice. IRRI.

Bona S, Jabeen M, Rahim F, Ilahi AI. 2005. Callus induction and regeneration in seed. Pak J Bot 37 (3): 829-836.

Bray EA. 2001. Plant response to water-deficit stress. Encyclopedia of Life Sciences.

Castillo EG, Tuong TP, Singh U, Inubushi K, Padilla J. 2006. Drought response of dry seeded rice to water stress timing, $\mathrm{N}$-fertilizer rates and sources. Soil Sci Plant Nutr 52: 496-508.

Chandra S, Rajib Bandopadhyay R, Kumar V, Chandra R. 2010 Acclimatization of tissue cultured plantlets: From laboratory to land. Biotechnol Lett 32 (9): 1199-205

Dami I, Hughes H. 1997. Effect of PEG- induced water stress on in vitro hardening of 'Valiant' Grape. Plant Cell Tissue Organ Cult 47: 97 184.

Djazuli M. 2010. Morpho-physiological characteristics of patchouli tolerant to drought stress. Bull Littro 21 (1): 8-17.

Haque MM, Mackill DJ, Ingram, KT. 1992. Inheritance of leaf epicuticular wax content in rice. Crop Sci 32: 865-868.

Hartati RRS, Suhesti S, Yunita R, Syafaruddin. 2018. Induction mutation using colchicine and in vitro selection using polyethylene glycal for Drought-tolerant sugarcane. Jurnal Littri 24 (2): 93-104. [Indonesian]

Hossain MF, Alam MS. 2001. Effect of gamma irradiation on the callus, developed from Indica rice. Pak J Biol Sci 4 (6): 670-671.

Husni A, Kosmiati M, Mariska I. 2006. Improvement of soybean (Sindoro) tolerance to drought stress through in vitro selection. Jurnal Agronomi Indonesia 34 (1): 25-31. [Indonesian]

Ikeuchi M, Sugimoto K, Iwase A, 2013. Plant callus: mechanisms of induction and repression. Plant Cell. 25: 3159-3173.
Joshi R, Shukla A, Sairam RK. 2011. In vitro screening of rice genotypes for drought tolerance using polyethylene glycol. Acta Physiol Plant 33: $2209-2217$.

Kadir A. 2011. Response of mutant rice genotypes resulting from gammaray irradiation to drought stress. J Agrivivor 10 (3): 235-246.

Lashari MI, Arshad M, Zafar Y, Asad S. 2008. Optimization of zeatin and explant type for efficient embryogenesis and plant regeneration of diploid cotton (Gossypium arboreum, L). J Agric Ress 46 (1): 1-13.

Lestari E G, Yunita R. 2008. Induksi kalus dan regenerasi tunas padi varietas Fatmawati. Jurnal Agronomi Indonesia 36 (2): 106-110. [Indonesian]

Mahmood I, Razzaq A. Ahmad M. 2012. In vitro selection of tissue culture-induced somaclonal variant of wheat for drought tolerance. $\mathrm{J}$ Agric Res 50 (2): 177-188.

Mostajeran A, Eichi VR. 2009. Effects of drought stress on growth and yields of rice (Oryza sativa L.) cultivars and accumulation of proline and soluble sugars in sheath and blades of their different ages leaves. Amer-Eurasian J Agric Environ Sci 5 (2): 264- 272.

Pantuwan G, Fukai S, Cooper M, Rajatasereekul S, O’Toole JC. 2002. Yield response of rice (Oryza sativa L,) genotype to drought under rainfed lowland, selection of drought-resistant genotypes. Field Crops Res 73: 169-180.

Rai MK, Kalia RK, Sinfh R, Gangola MP, Dhamwan AK. 2011. Developing stress-tolerant plant through in vitro selection -An overview of the recent progress. Environ Exp Bot 71 (1): 89-98.

Rao S, Jabeen FTZ. 2013. In vitro selection and characterization of polyethylene glycol (PEG) tolerant callus lines and regeneration of plantlets from the selected callus lines in sugarcane (Saccharum officinarum L.). Physiol Mol Biol Plants 19: 261-268.

Saleem MY, Mukhtar Z, Cheema AA, Atta BM. 2005. Induced mutation and in vitro techniques as a method to induce salt tolerance in basmati rice (Oryza sativa L.). Int J Environ Sci 2 (2): 141-145.

Sharma U, Kataria V, Shekhawat N S. 2017. In vitro propagation, ex vitro rooting and leaf micromorphology of Bauhinia racemosa Lam.: a leguminous tree with medicinal values. Physiol Mol Biol Plants 23 (4): 969-977.

Tariq M, Ali G, Shakeel FH, Ali M, Shah AA. 2008. Callus induction and in vitro plant regeneration of rice (Oryza sativa $\mathrm{L}$ ) under variation condition. Pak J Biol Sci 11 (2): 225-259.

Tsago Y, Andargie M, Takele A. 2014. In vitro selection of sorghum (Sorghum bicolor (L) Moench) for polyethylene glycol (PEG) induced drought stress. Plant Sci Today 1 (2): 62-68.

Wani SH, Sofi PA, Gosal SS, Singh NB. 2010. In vitro screening of rice (Oryza sativa L) callus for drought tolerance. Commun Biometry Crop Sci 5 (2): 108-115.

Yunita R, Khumaida N, Sopandie D, Mariska I. 2014. Effect of gamma irradiation on the growth callus and regeneration of rice variety Ciherang and Inpari 13. Jurnal AgroBiogen 10 (3): 101-108 [Indonesian] 